\title{
Physical weathering of carbonate host-rock by precipitation of soluble salts in caves: A case study in El Orón-Arco Cave (Region of Murcia, SE Spain)
}

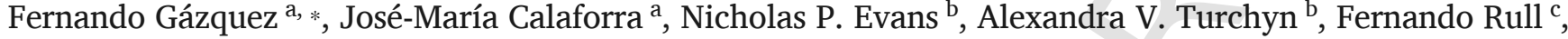 \\ Jesús Medina ${ }^{\mathrm{c}}$, Andrés Ros ${ }^{\mathrm{d}}$, José Luis Llamusí ${ }^{\mathrm{d}}$, Juan Sánchez ${ }^{\mathrm{d}}$, David A. Hodell ${ }^{\mathrm{b}}$ \\ a Department of Biology and Geology, Universidad de Almería, Carretera de Sacramento s.n, La Cañada de San Urbano, Almería 04120, Spain \\ ${ }^{\mathrm{b}}$ Department of Earth Sciences, University of Cambridge, Downing Street, Cambridge CB2 3EQ, United Kingdom \\ c Departamento de Física de la Materia Condensada, Cristalografía y Mineralogía, Universidad de Valladolid, Paseo de Belén, 7, 47011 Valladolid, Spain \\ d Centro de Estudios Ambientales y del Mar, CENM-naturaleza, Alcántara, 5, Cartagena, Murcia 30394, Spain
}

\section{A R T I C L E I N F O}

Editor: E. B Michael

\section{Keywords:}

Coastal caves

Evaporites

Gypsum

Halite

Salt weathering

Gypsum speleothems

Stable isotopes

\begin{abstract}
A B S T R A C T
The dissolution of carbonate host-rock by freshwater in phreatic or vadose conditions is the most common mech anism for the formation of caves; however, circulation of saline solutions through carbonate materials and precipitation of soluble salts may also play an important role. We studied the stable isotope composition $\left(\delta^{18} \mathrm{O}\right.$ and $\delta^{34} \mathrm{~S}$ of sulfate, $\delta^{18} \mathrm{O}$ and $\delta \mathrm{D}$ of structurally-bound gypsum hydration water and ${ }^{87} \mathrm{Sr} /{ }^{86} \mathrm{Sr}$ ) and salinity of fluid inclusions in gypsum speleothems found in El Orón-Arco Cave (Cartagena, SE Spain). We suggest that physical weathering of carbonate host-rock was driven by precipitation of soluble sea-salts (mostly gypsum and halite), and this process controlled the recent geomorphological evolution of the cave. The Triassic carbonate host-rock shows clear evidence for salt weathering, including gypsum/halite infillings in cracks of the bedrock, mechanical spalling of the carbonate, and detachment of rock fragments that lead to the formation cave voids and in-situ accumulations of piles of unsorted rubble. Sulfur and oxygen isotopes of gypsum sulfate $\left(3.0 \% \circ<\delta^{18} \mathrm{O}<11.6 \%\right.$ and $16.7 \% \circ<\delta^{34} S<20.7 \%$ ) are generally lower than modern seawater sulfate and suggest contributions from a ${ }^{34}$ S-depleted source (i.e. oxidation of pyrite). The $\delta^{18} \mathrm{O}$ and $\delta \mathrm{D}$ of gypsum hydration water are relatively low compared to expected values for the evaporation of pure seawater to gypsum saturation, suggesting that gypsum precipitation involved a secondary calcium-sulfate source or recycling of gypsum from previous stages, along with mixing of seawater and meteoric water seepage to the cave. The ${ }^{87} \mathrm{Sr} /{ }^{86} \mathrm{Sr}$ in gypsum shows intermediate values between modern seawater and Triassic carbonate values because of interaction between the solution and the bedrock. The salinities of the speleothem-forming solutions are relatively high $(13.2 \pm 3.2 \mathrm{wt} \% \mathrm{eq}$. $\mathrm{NaCl})$ compared to gypsum formed from evaporated brackish solutions (i.e. $\sim 4-8 \mathrm{wt} \% \mathrm{eq}$. $\mathrm{NaCl}$ ) and indicate dissolution of earlier evaporites before secondary gypsum precipitation. This cave-forming mechanism, which is related to saline water circulation and precipitation of evaporitic minerals, may be common in other coastal caves.
\end{abstract}

\section{Introduction}

The mechanisms involved in the formation of caves (i.e. speleogenesis) are generally linked to dissolution of carbonate host-rock by freshwaters undersaturated in calcium carbonate (see Audra and Palmer, 2015 for a recent review). These karstification processes create voids in the rock that can result in the breakdown and collapse of cave ceilings,

\footnotetext{
* Corresponding author.

Email address: f.gazquez@ual.es (F. Gázquez)
}

eventually leading to the formation of large chambers and passages (Ginés and Ginés, 2007).

In the case of coastal caves, the dissolution of the carbonate host-rock can be enhanced by the mixing of freshwater and seawater that generates solutions undersaturated in calcite $\left(\mathrm{CaCO}_{3}\right)$ and dolomite $\left(\mathrm{CaMg}\left(\mathrm{CO}_{3}\right)_{2}\right)$. These undersaturated solutions are capable of dissolving limestone and dolostones, accelerating cave forming processes (Mylroie and Mylroie, 2007). In addition to karstification processes, speleogenesis in coastal caves can be driven by the geomorphological evolution of 
the shoreline, in many cases connected to coastal erosion that causes landslides and fracturing (Moore, 1954). Caves that develop in coastal fractures (e.g. 'flank margin caves') display distinctive features compared to caves formed by dissolution (Mylroie and Carew, 1990) and lack specific features generated by a subterranean water course or phreatic conduits, such as 'scallops' and smoothed surfaces (Mylroie and Mylroie, 2007). Additional geochemical processes in coastal karstic aquifers can also result in the formation of subterranean voids; potential mechanisms include mechanical weathering caused by the pressure generated in pores of the carbonate host-rock because of the precipitation of soluble salts (i.e. 'gypsum/halite wedging'; White and White, 2003). However, the relative importance of salt weathering processes in coastal cave environments remains uninvestigated.

Salt weathering is known to influence the development of many geomorphologic features in different environments, including honeycombs and alveoles (Mustoe, 1982), tafoni, and cave genesis in granitic rocks (Bradley et al., 1978). Furthermore, this mechanism is an important contributor to rock debris generation in arid regions (Beaumont, 1968; Goudie and Day, 1980), coastal environments (Mottershead, 1989), and cold settings (Prebble, 1967). In this study, we examine the mineralogy and geochemistry of secondary evaporite deposits in El Orón-Arco Cave of Cabo Tiñoso ('Scabby Cape', Cartagena, Region of Murcia, SE Spain) in order to evaluate the role of sea salt weathering during its formation. Oxygen and sulfur isotopes of sulfate in gypsum $\left(\mathrm{CaSO}_{4} \cdot 2 \mathrm{H}_{2} \mathrm{O}\right)$ are utilized to determine the sources of sulfate for the formation of the gypsum speleothems. Oxygen and hydrogen isotopes in structurally-bonded gypsum hydration water (GHW) and salinity of fluid inclusions (i.e. microthermometry of fluid inclusions) are used to identify the source of water (seawater vs meteoric seepage; e.g. Evans et al., 2015), the degree of evaporation of the solution in the cave, and potential recycling of older evaporites before the precipitation of the gypsum speleothems. Strontium isotopes in gypsum and soluble salts in pores of the host-rock are used as an indicator of the degree of contribution of cations (calcium and strontium) from the cave matrix to the solution before gypsum precipitation. We generate a model to explain the cave formation based on geomorphological and geochemical observations, with potential implications for the genesis of other coastal caves.

\section{Geological setting and cave description}

El Orón-Arco Cave system is located in the southern flank of Cabo Tiñoso in Cartagena, Murcia Region, SE Spain (Fig. 1). The cavity consists of a subterranean network that extends over $1500 \mathrm{~m}$, from El Arco Cave in the south-east, first surveyed in the 1980s (Llamusí et al., 1990), to the more recently discovered El Orón Cave in the north-west (Puch, 1998). El Arco Cave is also known as the 'Cave of the Great Lake' because of the presence of a $1200 \mathrm{~m}^{2}$ brackish lake with a maximum depth of $2 \mathrm{~m}$. The largest cave chamber is the 'Hall of the Chandeliers', which is located between 40 and 170 ma.s.l., representing the highest point in the cave above sea level. The rest of the passages and chambers lie between the sea level and $\sim 40$ ma.s.l. There are two entrance locations to El Orón-Arco Cave; the first is via a submarine access point ( $2 \mathrm{mb}$ b.s.l.), whereas the second consists of a subaerial entrance in the cliff of Cabo Tiñoso ( 10 ma.s.l.) (Fig. 1$)$.

The cave has formed along a fracture running NW to SE, parallel to the shoreline, in the highly foliated Triassic limestone and dolostone of the Alpujarride Formation of Cabo Tiñoso (García-Tortosa et al., 2000). A series of greyish limestones and interbedded reddish dolostones outcrop both in the cave (Fig. 2A) and outside (Fig. 2B). No evidence for phreatic dissolution or signs of subterranean runoff are found in the cave, whereas two brackish-water lakes at sea-level are the only known waterbodies at present.
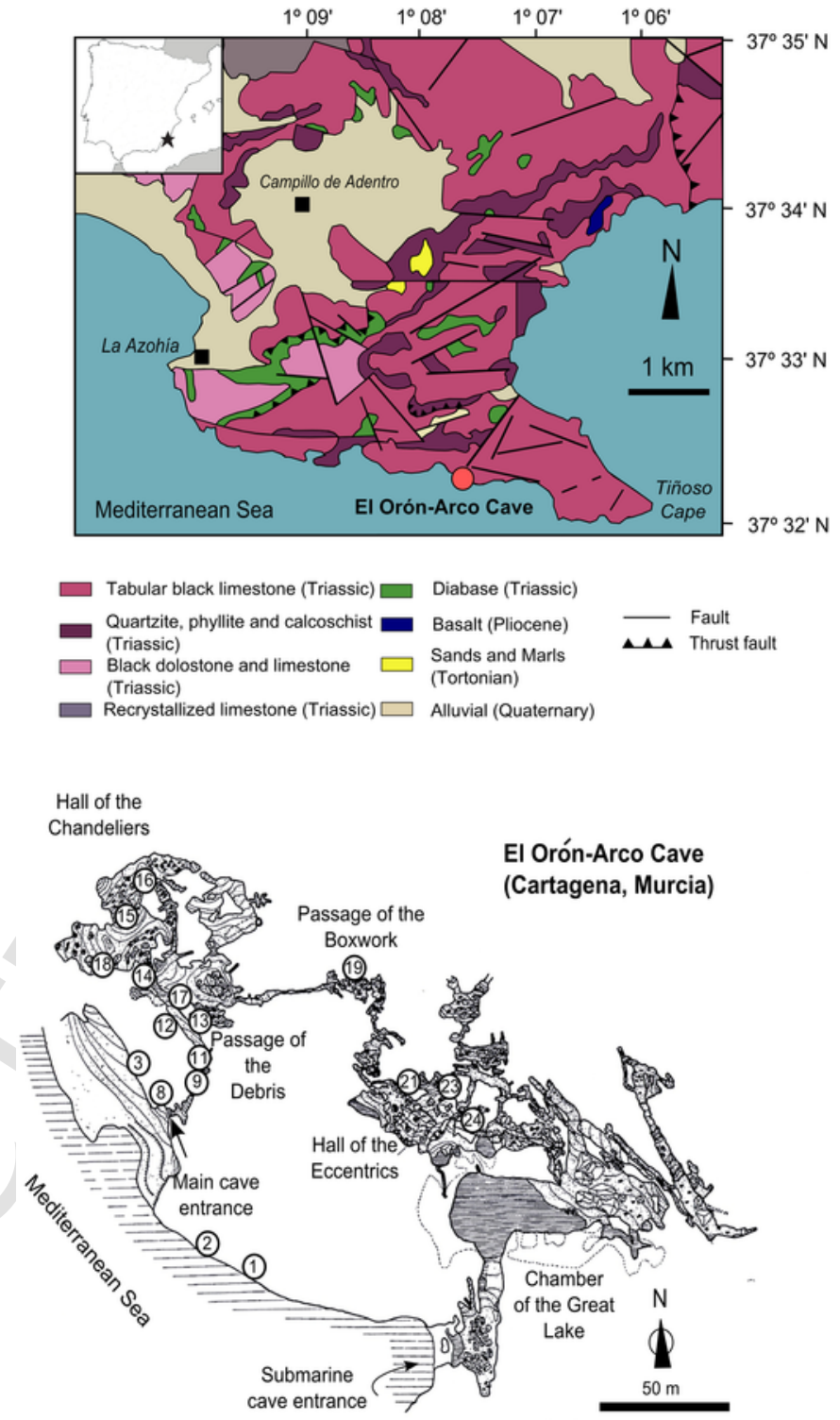

Fig. 1. Geological setting of Cabo Tiñoso (after Gordillo et al., 1972) and topography of El Orón-Arco Cave (produced by Llamusí, Inglés and Ros, 1984-1998). Sampling sites are indicated.

Climate in this region is semi-arid, with mean annual temperature around $20^{\circ} \mathrm{C}$, maximum temperatures in August $\left(\sim 28^{\circ} \mathrm{C}\right)$ and minimum in January $\left(\sim 14^{\circ} \mathrm{C}\right)$. Average annual precipitation rarely exceeds $250 \mathrm{~mm}$ in this region and is one of the driest areas of the Iberian Peninsula. Vegetation over the cave consists of thermo-Mediterranean pre-desertic scrubs and xerophilic herbs.

\section{Methods}

\subsection{Sampling of speleothems}

We performed a detailed photographic study of the geomorphological and speleothemic features of El Orón-Arco Cave (Figs. 2 and 3) and collected 27 mineral samples for mineralogical and stable isotopes analyses (Fig. 1 for sampling site locations; Figs. 2 and 3 and Table 1 for sample descriptions). In general, sample amounts were smaller than $5 \mathrm{~g}$ and were preferentially selected from discreet parts of the chambers to minimize the impact on the cave environment. 

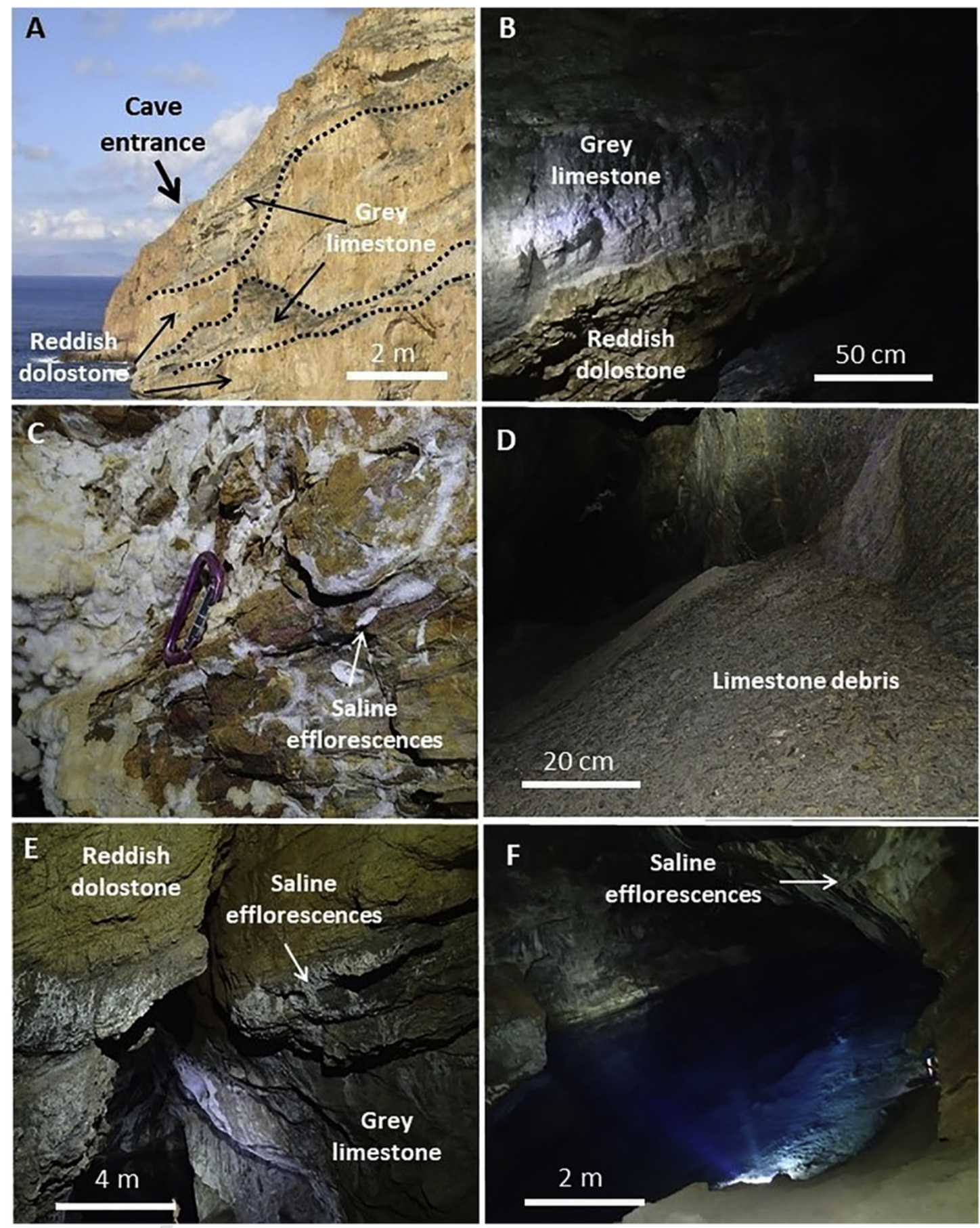

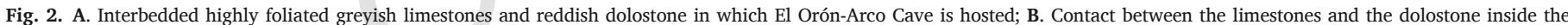

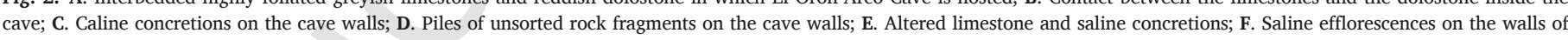
the Hall of the Great Lake.

Saline concretions on the cave walls were sampled from foliation planes of the host-rock in different sectors of the cave $(n=8)$ (Figs. $2 \mathrm{~A}$ and 3 ). We took samples of the foliated greyish and reddish materials that comprise the host-rock inside and outside the cave $(n=4)$ (Fig. 2B), and one sample of yellowish calcschists from outside of the cave entrance. A sample of yellowish unconsolidated, sandy material was taken from a fracture following the foliation of the greyish host-rock in the Hall of the Chandeliers. In the same chamber, a sample of the whitish microcrystalline crust that occurs all over the ceiling in this location was collected (Fig. 3E). Another sample comprises a $\sim 5 \mathrm{~cm}$ frag- ment from a $\sim 1 \mathrm{~m}$ long transparent euhedral crystal that hangs from the cave ceiling, resembling a 'chandelier' (Fig. 3E), and morphologically similar to those described in Lechuguilla Cave, New Mexico, USA (Davis, 2000). In places, the apices of these crystals display a $\sim 10 \mathrm{~cm}$ long and $1 \mathrm{~cm}$ wide hollow cylinder, resembling a soda-straw, made of a transparent microcrystalline mineral (Fig. 3F). In the 'Hall of the Eccentrics', we took a $\sim 5 \mathrm{~g}$ fragment of a hollow gypsum hemisphere, $\sim 20 \mathrm{~cm}$ in diameter from the cave ceiling (called 'blisters' hereafter), which are surrounded by (but generally not in contact with) carbonate speleothems (Fig. 3H). Similar 'blister' speleothems have been described in Cupp-Coutunn Cave, Turkmenistan (Maltsev and Self, 1992). 

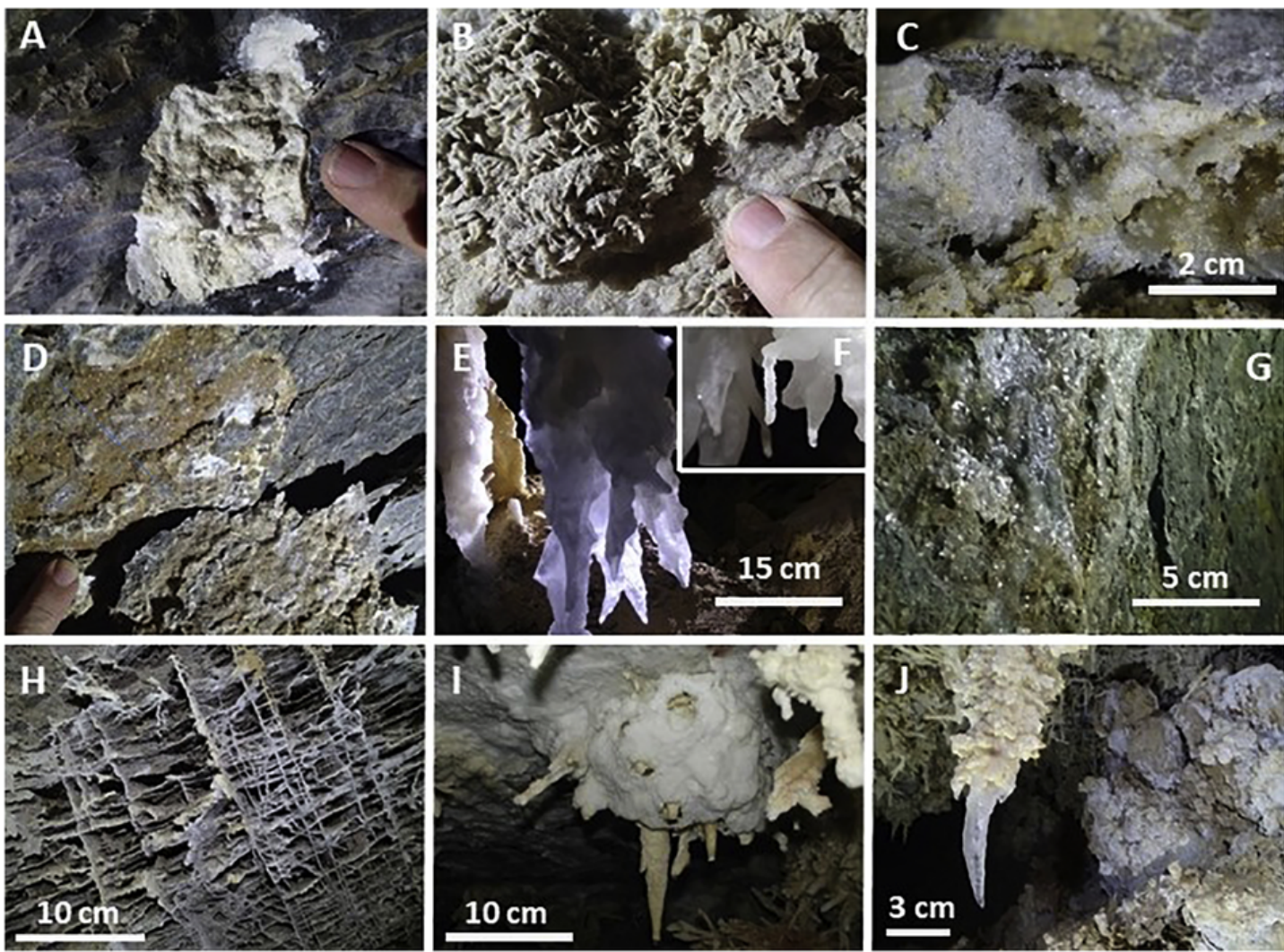

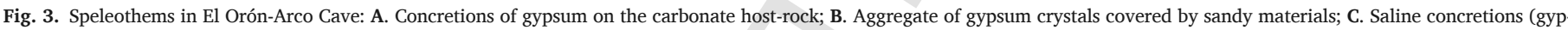

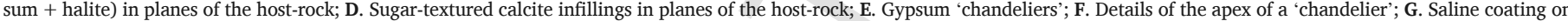

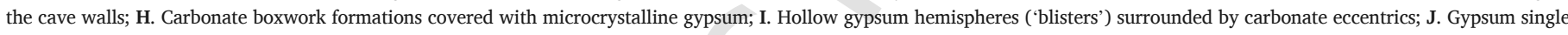
crystals hanging from the tip of a carbonate dripstone.

Lastly, a transparent single crystal was collected from the tip of a stalactite (Fig. 3I). Samples $(\sim 250 \mathrm{mg})$ were ground to a fine powder and dried at $45^{\circ} \mathrm{C}$ overnight for mineralogical and isotopic analyses.

\subsection{Mineralogical analyses}

A transmission X-ray diffraction (XRD) instrument (Terra), inXitu, Inc. (California), was utilized to determine the mineralogy of 27 samples (Sarrazin et al., 2005) at the Unidad Asociada al Centro de Astrobiologia CAB-CSIC-UVa of Valladolid University (Valladolid, Spain). Powdered samples were initially transferred into a vibrating cell. A micro-focused X-ray source $(\mathrm{Co})(10 \mathrm{~W})$ was combined with miniature slits to produce a low divergence beam illuminating the sample at a $10^{\circ}$ incidence angle. A custom CCD camera (Andor ${ }^{\mathrm{TM}}$ ) was used to collect the XRD signal over a range of $5-55^{\circ}$ of $2 \theta$. X-ray diffractogram resolution was $0.3^{\circ}$ of the $2 \theta$ angle. Sections of diffraction rings were collected in 2D images, while the 1D XRD patterns were calculated by circumferential integration of the diffracted intensities along diffraction rings. Diffractograms were processed by the X-Powder software (Martín, 2004) and mineralogical determination used the PDF-2 (Power Diffraction Files) database.

\subsection{Stable isotope analyses}

\subsubsection{Sulfur $\left(\delta^{34} S\right)$ and oxygen $\left(\delta^{18} \mathrm{O}_{\mathrm{SO}}\right)$ in sulfate}

The sulfur and oxygen isotopes of the sulfate of 13 samples were analyzed in the Godwin Laboratory at the University of Cambridge (UK). Powdered gypsum samples ( $\sim 5 \mathrm{mg}$ ) were dissolved in deionized water at $45^{\circ} \mathrm{C}$ overnight. The effluent containing the aqueous sulfate from the dissolution was then separated, and a barium chloride solu- tion $(50 \mathrm{~g} / \mathrm{L})$ was added to induce $\mathrm{BaSO}_{4}$ precipitation. The $\mathrm{BaSO}_{4}$ was rinsed with $6 \mathrm{M} \mathrm{HCl}$ to remove carbonates, and subsequently rinsed 3 times with deionized water. The samples were then dried at $45^{\circ} \mathrm{C}$ overnight.

For $\delta^{18} \mathrm{O}_{\mathrm{SO} 4}$, a High Temperature Conversion Element Analyzer (TC/ EA) was used to pyrolyze the $\mathrm{BaSO}_{4}$ at $1450^{\circ} \mathrm{C}$ and produce $\mathrm{CO}$, which was measured by continuous flow Gas Source Isotope Ratio Mass Spectrometry (ThermoScientific Delta V Plus). All $\delta^{18} \mathrm{O}_{\mathrm{SO} 4}$ are reported relative to V-SMOW (Vienna-Standard Mean Ocean Water). Samples were run in triplicate, alongside the NBS-127 Standard (8.6\%), and the standard deviation of the replicate analyses was better than $0.5 \%$ o $(1 \sigma)$.

For $\delta^{34} \mathrm{~S}_{\mathrm{SO} 4}$, the $\mathrm{BaSO}_{4}$ was combusted at $1030{ }^{\circ} \mathrm{C}$ in a Flash Elemental Analyzer (Flash-EA), and the sulfur dioxide produced was measured by continuous flow Gas Source Isotope Ratio Mass Spectrometry (ThermoScientific, Delta V Plus). All $\delta^{34} \mathrm{~S}_{\mathrm{SO} 4}$ are reported relative to VCDT (Vienna-Canyon Diablo Troilite). Samples for sulfur isotope analysis were run in duplicate, alongside the NBS-127 standard (20.3\%o). The reproducibility $(1 \sigma)$ of $\delta^{34} \mathrm{~S}_{\mathrm{SO} 4}$ of the duplicate analyses was better than $0.2 \%$, similar to the long-term reproducibility of the NBS-127 over the run $(0.2 \%$ ) .

\subsection{2. $\delta^{18} \mathrm{O}$ and $\delta D$ of gypsum hydration water (GHW)}

The GHW of 8 samples was extracted by slowly heating each sample $(\sim 200 \mathrm{mg})$ to $400^{\circ} \mathrm{C}$, in vacuo, using a bespoke offline extraction system consisting of six vacuum lines contained within a modified gas chromatography (GC) oven, following the method of Gázquez et al. (2015a). Oxygen $\left(\delta^{18} \mathrm{O}\right)$ and hydrogen $(\delta D)$ isotopes in GHW were measured simultaneously by cavity ring down spectroscopy (CRDS) in the Godwin Laboratory at the University of Cambridge (UK) using a L1102-i Picarro water isotope analyzer (Hodell et al., 2012; Evans et 
Table 1

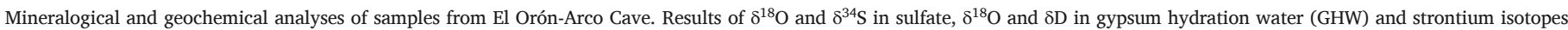

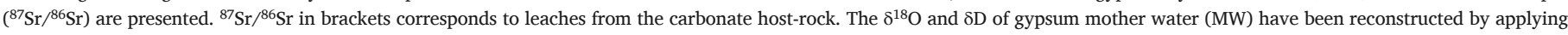

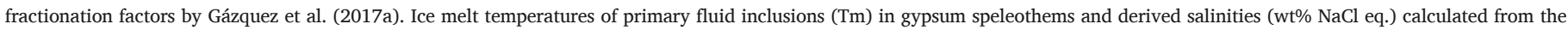
equation of Bodnar (1993), are also given.

\begin{tabular}{|c|c|c|c|c|c|c|c|c|c|c|c|c|}
\hline Sample & Description & Site & Mineralogy & $\delta^{34} \mathrm{~S}_{\mathrm{SO} 4}$ & $\delta^{18} \mathrm{O}_{\mathrm{SO} 4}$ & $\delta^{18} \mathrm{O}_{\mathrm{GHW}}$ & $\delta \mathrm{D}_{\mathrm{GHW}}$ & $\delta^{18} \mathrm{O}_{\mathrm{MW}}$ & $\delta \mathrm{D}_{\mathrm{MW}}$ & $\operatorname{Th}\left({ }^{\circ} \mathrm{C}\right)$ & $\% \mathrm{NaCl}$ eq & ${ }^{87} \mathrm{Sr} /{ }^{86} \mathrm{Sr}$ \\
\hline CT-01 & $\begin{array}{l}\text { Yellowish } \\
\text { calcschist }\end{array}$ & Outside & Calcite & - & - & - & - & - & - & - & - & \\
\hline CT-02 & Grey host-rock & Outside & Calcite & - & - & - & - & - & - & - & - & \\
\hline CT-03 & $\begin{array}{l}\text { Infillings along } \\
\text { host-rock strata }\end{array}$ & Outside & $\begin{array}{l}\text { Halite, } \\
\text { gypsum (-) }\end{array}$ & - & - & - & - & - & - & - & - & \\
\hline CT-08 & Grey limestone & Outside & $\begin{array}{l}\text { Calcite, } \\
\text { dolomite } \\
(-)\end{array}$ & - & - & - & - & - & - & - & - & $\begin{array}{l}0.707737 \\
(0.707988)\end{array}$ \\
\hline CT-09 & $\begin{array}{l}\text { Whitish coating } \\
\text { on host-rock }\end{array}$ & $\begin{array}{l}\text { Entrance } \\
\text { passage }\end{array}$ & Gypsum & 17.7 & 8.4 & - & - & - & & - & - & \\
\hline CT-11 & $\begin{array}{l}\text { Gypsum 'rose' in } \\
\text { sediment }\end{array}$ & $\begin{array}{l}\text { Entrance } \\
\text { passage }\end{array}$ & Gypsum & 19.6 & 8.3 & - & - & - & - & - & - & \\
\hline CT-12 & $\begin{array}{l}\text { Sugary texture } \\
\text { brownish infillings }\end{array}$ & $\begin{array}{l}\text { Passage of } \\
\text { the debris }\end{array}$ & $\begin{array}{l}\text { Calcite, } \\
\text { dolomite } \\
(-)\end{array}$ & & & & & & & & & \\
\hline CT-13 & $\begin{array}{l}\text { Crystalline } \\
\text { coatings on the } \\
\text { cave wall }\end{array}$ & $\begin{array}{l}\text { Passage of } \\
\text { the debris }\end{array}$ & $\begin{array}{l}\text { Gypsum, } \\
\text { celestine (-) }\end{array}$ & 19.2 & 5.8 & - & - & & - & - & - & 0.708188 \\
\hline CT-14 & Reddish host-rock & $\begin{array}{l}\text { Hall of the } \\
\text { chandeliers }\end{array}$ & $\begin{array}{l}\text { Dolomite, } \\
\text { goethite }(-)\end{array}$ & & & & & & & & & \\
\hline CT-15A & $\begin{array}{l}\text { Microcrystalline } \\
\text { coatings over } \\
\text { chandeliers }\end{array}$ & $\begin{array}{l}\text { Hall of the } \\
\text { chandeliers }\end{array}$ & Gypsum & 17.0 & - & 5.5 & -16.9 & 2.2 & 3.2 & - & - & \\
\hline СТ-15B & $\begin{array}{l}\text { Gypsum } \\
\text { chandelier (1) }\end{array}$ & $\begin{array}{l}\text { Hall of the } \\
\text { chandeliers }\end{array}$ & Gypsum & 17.7 & 4.7 & 5.8 & -13.6 & 2.5 & 1.4 & $-10.7 \pm 2.5$ & $14.2 \pm 2.5$ & 0.708183 \\
\hline CT-15C & Halite soda-straw & $\begin{array}{l}\text { Hall of the } \\
\text { chandeliers }\end{array}$ & $\begin{array}{l}\text { Halite, } \\
\text { celestine (-) }\end{array}$ & - & - & & - & - & - & - & - & \\
\hline CT-16 & $\begin{array}{l}\text { Gypsum } \\
\text { chandelier (2) }\end{array}$ & $\begin{array}{l}\text { Hall of the } \\
\text { chandeliers }\end{array}$ & Gypsum & 17.0 & 3.0 & 4.8 & -16.9 & 1.5 & -2.0 & - & - & \\
\hline CT-17 & $\begin{array}{l}\text { Microcrystalline } \\
\text { gypsum }\end{array}$ & $\begin{array}{l}\text { Passage of } \\
\text { the debris }\end{array}$ & Gypsum & 17.1 & 7.5 & 4.3 & -21.4 & 1.0 & -6.5 & - & - & \\
\hline CT-18A & $\begin{array}{l}\text { Yellowish powder } \\
\text { in planes of the } \\
\text { host-rock }\end{array}$ & $\begin{array}{l}\text { Hall of the } \\
\text { chandeliers }\end{array}$ & $\begin{array}{l}\text { Halite, } \\
\text { gypsum, } \\
\text { quartz (-) }\end{array}$ & 17.0 & - & - & - & - & - & - & - & \\
\hline CT-18B & Reddish host-rock & $\begin{array}{l}\text { Hall of the } \\
\text { chandeliers }\end{array}$ & $\begin{array}{l}\text { Dolomite, } \\
\text { goethite (-) }\end{array}$ & - & - & - & - & - & - & - & - & $\begin{array}{l}0.707835 \\
(0.707926)\end{array}$ \\
\hline CT-18D & $\begin{array}{l}\text { Whitish veins in } \\
\text { the host-rock }\end{array}$ & $\begin{array}{l}\text { Hall of the } \\
\text { chandeliers }\end{array}$ & Calcite & - & - & - & - & - & - & - & - & \\
\hline CT-19A & $\begin{array}{l}\text { Whitish coatings } \\
\text { on boxwork }\end{array}$ & $\begin{array}{l}\text { Hall of the } \\
\text { boxwork }\end{array}$ & Gypsum & 20.7 & 11.6 & 3.4 & -18.9 & 0.1 & -4.0 & - & - & \\
\hline СТ-19B & Boxwork laminae & $\begin{array}{l}\text { Hall of the } \\
\text { boxwork }\end{array}$ & $\begin{array}{l}\text { Dolomite, } \\
\text { calcite }(-)\end{array}$ & - & - & - & - & - & - & - & - & \\
\hline CT-21B & Stalactite & $\begin{array}{l}\text { Hall of the } \\
\text { eccentrics }\end{array}$ & Aragonite & - & - & - & - & - & - & - & - & \\
\hline CT-21A & $\begin{array}{l}\text { Spar on the tip of } \\
\text { a stalactite }\end{array}$ & $\begin{array}{l}\text { Hall of the } \\
\text { eccentrics }\end{array}$ & Gypsum & 16.7 & 5.8 & 4.1 & -18.8 & 0.8 & -3.9 & $-9.9 \pm 2.4$ & $13.3 \pm 2.4$ & \\
\hline CT-21C & $\begin{array}{l}\text { 'Blister' } \\
\text { speleothem (1) }\end{array}$ & $\begin{array}{l}\text { Hall of the } \\
\text { eccentrics }\end{array}$ & Gypsum & 17.1 & 7.4 & 2.6 & -24.8 & -0.7 & -9.9 & - & - & 0.708095 \\
\hline CT-23A & $\begin{array}{l}\text { Microcrystalline } \\
\text { coating over } \\
\text { stalactite }\end{array}$ & $\begin{array}{l}\text { Hall of the } \\
\text { eccentrics }\end{array}$ & Gypsum & 18.4 & 9.8 & - & - & - & - & - & - & \\
\hline CT-23A1 & $\begin{array}{l}\text { Spar on the tip of } \\
\text { a stalactite }\end{array}$ & $\begin{array}{l}\text { Hall of the } \\
\text { eccentrics }\end{array}$ & Gypsum & - & - & - & - & - & - & $-5.3 \pm 1.9$ & $8.2 \pm 2.6$ & \\
\hline CT-23B & Stalactite & $\begin{array}{l}\text { Hall of the } \\
\text { eccentrics }\end{array}$ & Aragonite & - & - & - & - & - & - & - & - & \\
\hline CT-23C & Stalactite & $\begin{array}{l}\text { Hall of the } \\
\text { eccentrics }\end{array}$ & Aragonite & - & - & - & - & - & - & - & - & \\
\hline CT-24 & $\begin{array}{l}\text { 'Blister' } \\
\text { speleothem (2) }\end{array}$ & $\begin{array}{l}\text { Hall of the } \\
\text { eccentrics }\end{array}$ & Gypsum & 17.9 & 7.8 & 2.0 & -24.7 & -2.3 & -9.9 & - & - & \\
\hline
\end{tabular}

al., 2015; Chen et al., 2016). All results are reported in parts per thousand $(\% \circ)$ relative to V-SMOW. Calibration of results to V-SMOW was achieved by analyzing internal standards before and after each set of 10 or 12 samples. Internal standards were previously calibrated against V-SMOW, GISP, and SLAP. External error $(1 \sigma)$ of the method was $\pm 0.1 \%$ for $\delta^{18} \mathrm{O}$ and $\pm 0.6 \%$ for $\delta \mathrm{D}$, as estimated by repeated analysis $(n=3)$ of an analytical grade standard, extracted together with the samples in each run of the extraction apparatus (Gázquez et al., 2015a).

\subsubsection{Strontium isotopes}

Strontium isotope $\left({ }^{87} \mathrm{Sr} /{ }^{86} \mathrm{Sr}\right)$ measurements were made by thermal ionization mass spectrometry (Thermo-Scientific Triton Plus MC-TIMS) at the University of Cambridge. Approximately $2.5 \mathrm{mg}$ of powdered gypsum $(n=3)$ was processed for isotopic analysis. Gypsum was ground to a fine powder and dissolved in deionized water. Carbonate samples were also ground placed deionized water for $24 \mathrm{~h}$ to extract soluble salts. The supernatant fluid was stored for isotopic analysis 
$(n=2)$. The carbonate samples themselves $(n=2)$ were prepared for isotope analysis by treating the samples with methanol, $10 \%$ ammonium hydroxide and water washes (to mechanically remove clays and adsorbed ions), each step performed in triplicate. To isolate the carbonate phase, the solid sample was dried, weighed and placed in a volume of $0.1 \mathrm{M} \mathrm{HCl}$ containing $110 \%$ of the acid required for complete dissolution of the carbonate, calculated to avoid elemental variation generated by incomplete dissolution.

An aliquot of each sample solution containing approximately $300 \mathrm{ng}$ of strontium was dried down, dissolved in $200 \mu \mathrm{L} 3 \mathrm{M} \mathrm{HNO}_{3}$ and refluxed at $80^{\circ} \mathrm{C}$ for $3 \mathrm{~h}$. Strontium was separated using Eichrom Sr Spec resin with $100 \mu \mathrm{m}$ to $150 \mu \mathrm{m}$ mesh particle size in clean lab conditions. The separated $\mathrm{Sr}$ was dried down, refluxed in $3 \mathrm{~N} \mathrm{HNO}_{3}$ and subsequently dried down once again. Samples were then loaded onto degassed single Re filaments together with $1 \mu \mathrm{L}$ of tantalum phosphate activator. A current of $\sim 0.8 \mathrm{~A}$ was continuously applied during the loading. The evaporation filament is heated manually until a stable signal between $4 \mathrm{~V}$ and $6 \mathrm{~V}$ of ${ }^{88} \mathrm{Sr}$ on a $10^{11} \Omega$ resistor was reached. Data acquisition was comprised of 10 blocks of 20 measurements with a $\sim 8 \mathrm{~s}$ integration time in static mode. Results were normalized to ${ }^{88} \mathrm{Sr} /{ }^{86} \mathrm{Sr} 0.1194$ with an exponential fractionation correction. Runs were bracketed with the NBS 987 standard. Eleven analyses of NBS 987 during 2 months before and after this study gave a mean value of $0.710253(2 \sigma=0.000007)$. Blanks were $<250 \mathrm{pg}$ and negligible for the Sr concentration of these samples.

\subsection{Microthermometry of fluid inclusions}

The method for microthermometric analysis of fluid inclusions in gypsum closely followed that described by Attia et al. (1995) and Evans et al. (2015). Thin ( $<1 \mathrm{~mm}$ ) sections of gypsum were obtained by cleaving the mineral along 010 planes using a razor blade. The fragments were placed in a Linkam THMSG600 heating-freezing stage attached to a Zeiss Axio Scope.A1 microscope. The ice melt temperature $\left(\mathrm{T}_{\mathrm{m}}\right)$ of primary fluid inclusions (identified as described in Attia et al., 1995) in samples CT-15B $(n=11)$, CT-21B $(n=10)$ and CT-23 $(n=4)$ was determined following the procedure described by Evans et al. (2015). $\mathrm{T}_{\mathrm{m}}$ was recorded to within $0.1{ }^{\circ} \mathrm{C}$ and reproduced at least twice for each inclusion with an error of $\pm 0.2^{\circ} \mathrm{C}$. Salinities of the fluid inclusions were calculated from the final $\mathrm{T}_{\mathrm{m}}$ and expressed as weight $\% \mathrm{NaCl}$ equivalent (Bodnar, 1993).

\section{Results}

\subsection{Mineralogy}

The cave host-rock comprises an alternate sequence of limestone (grey materials) and dolostone (reddish materials) beds that outcrop inside and outside the cave (Fig. 2A and B). Most of the concretions, infillings and coatings in the Passage of the Debris and the Hall of the Chandeliers are made of microcrystalline gypsum (Fig. $3 \mathrm{C}$ ) and halite $(\mathrm{NaCl})$ (Fig. $3 \mathrm{G})$, with minor dolomite and celestine $\left(\mathrm{SrSO}_{4}\right)$ and occasionally brownish sugary-textured calcite (Fig. 3D). The mineralogical analyses confirm that the microcrystalline coatings in the ceiling of the Hall of the Chandeliers and in the selenite crystals of the 'chandeliers' (Fig. 3E) are made of high-purity gypsum. The apices of some of the chandeliers are made of a halite cylinder, containing traces of celestine (Fig. 3F). The 'boxwork' structures of the 'Hall of the Boxwork' is composed of dolomite blades (with minor calcite), covered by gypsum coatings (Fig. 3G). In the Hall of the Eccentrics, the 'blister' speleothems are made of gypsum, while the inner stalactites are composed of aragonite (Fig. 3I). All the analyzed stalactites in this chamber are composed of aragonite, which in places display single gypsum crystals hanging from their tips (Fig. 3J).

\subsection{Stable isotopes}

\subsubsection{Sulfur and oxygen in sulfate}

The $\delta^{34} \mathrm{~S}$ values in gypsum speleothems range from $16.7 \%$ to $20.7 \%$, and the $\delta^{18} \mathrm{O}_{\mathrm{SO} 4}$ in sulfate ranges from $3.0 \%$ o to $11.6 \%$. The $\delta^{34} \mathrm{~S}$ and $\delta^{18} \mathrm{O}_{\mathrm{SO} 4}$ show a positive correlation with slope of 1.3 (Fig. 4). The gypsum coatings from the Passage of the Boxwork display higher $\delta^{34} \mathrm{~S}$ and $\delta^{18} \mathrm{O}_{\mathrm{SO} 4}$, within the range of modern marine sulfate $(\sim 20 \%$ o and $\sim 9 \%$, respectively). The rest of samples fall out of this range and generally have lower $\delta^{34} \mathrm{~S}$ and $\delta^{18} \mathrm{O}_{\mathrm{SO} 4}$ values.

\subsection{2. $\delta^{18} \mathrm{O}$ and $\delta D$ of gypsum hydration water}

The $\delta^{18} \mathrm{O}$ and $\delta \mathrm{D}$ in GHW of speleothems from El Orón-Arco Cave range from $2.0 \%$ to $5.8 \%$ and from $-24.8 \%$ o to $-13.6 \%$, respectively. The oxygen and hydrogen isotope composition of the parent water from which the gypsum formed is calculated by using the values of GHW and known fractionation factors $\left(\alpha^{18} \mathrm{O}_{\text {gypsum-water }}\right.$ and $\left.\alpha \mathrm{D}_{\text {gypsum-water }}\right)$, which are practically insensitive to temperature between $5{ }^{\circ} \mathrm{C}$ and $30^{\circ} \mathrm{C}$ (Gázquez et al., 2017a; Liu et al., 2018). The $\alpha \mathrm{D}_{\text {gypsum-water }}$ is relatively sensitive to water salinity $\left(3 \times 10^{-5}\right.$ per $\mathrm{g} / \mathrm{L}$ of $\mathrm{NaCl}$ between $30 \mathrm{~g} / \mathrm{L}$ and $300 \mathrm{~g} / \mathrm{L}$ ), whereas $\alpha^{18} \mathrm{O}_{\text {gypsum-water }}$ is not affected by salinities $<150 \mathrm{~g} /$ L of $\mathrm{NaCl}$ (Gázquez et al., 2017a). Gypsum samples in this study precipitated mostly from solutions with salinities around 130-150 g/L (see Section 4.3). We use fractionation factors at $150 \mathrm{~g} / \mathrm{L}\left(\alpha^{18} \mathrm{O}_{\text {gypsum-water }}\right.$ of 1.0033 and $\alpha \mathrm{D}_{\text {gypsum-water }}$ of 0.985 ; Gázquez et al., 2017a). Changes in temperature of $\pm 5{ }^{\circ} \mathrm{C}$, result in uncertainty of $\pm 0.5 \%$ in the calculated values of $\delta \mathrm{D}$ of the mother water, which is insignificant given the analytical precision of the measurements $( \pm 0.6 \%$ ). Changes in salinity of $\pm 50 \mathrm{~g} / \mathrm{L}$ would result in uncertainties of $\pm 1.5 \%$ in $\delta \mathrm{D}$ of the mother water, which is also irrelevant for our application.

By applying the selected isotope fractionation factors to the isotope composition of GHW, we found that the $\delta^{18} \mathrm{O}$ of the speleothem-forming water ranges from $-0.7 \%$ to $2.5 \%$, while $\delta \mathrm{D}$ ranges from $-9.9 \%$ o to $3.2 \%$. The speleothems from the Hall of the Eccentrics show the lower $\delta^{18} \mathrm{O}$ and $\delta \mathrm{D}$ values, whereas gypsum in the Hall of the Chandeliers precipitated from a solution more enriched in the heavy isotopes (Table 1 and Fig. 5). Together, the $\delta^{18} \mathrm{O}$ and $\delta \mathrm{D}$ of the speleothem-forming water values describe a line with a slope of $\sim 3.3$.

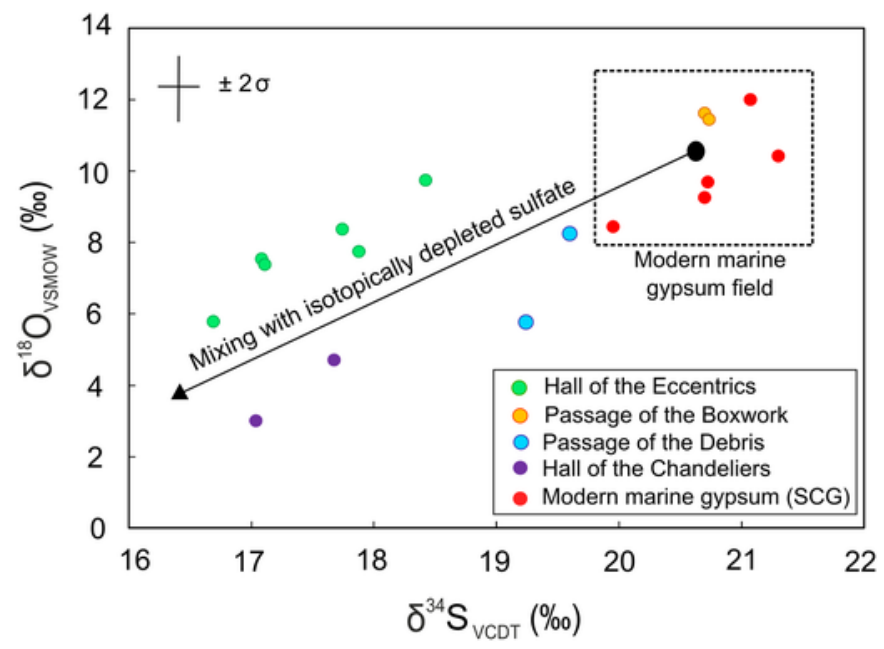

Fig. 4. Sulfur and oxygen isotope composition of gypsum speleothems from El Orón-Arco Cave. The $\delta^{34} \mathrm{~S}$ and $\delta^{18} \mathrm{O}_{\mathrm{SO} 4}$ values of modern marine gypsum (SCG samples) from a nearby salt factory (Salina of Cabo de Gata, Almeria, SE Spain; Evans et al., 2015) are presented for comparison. 


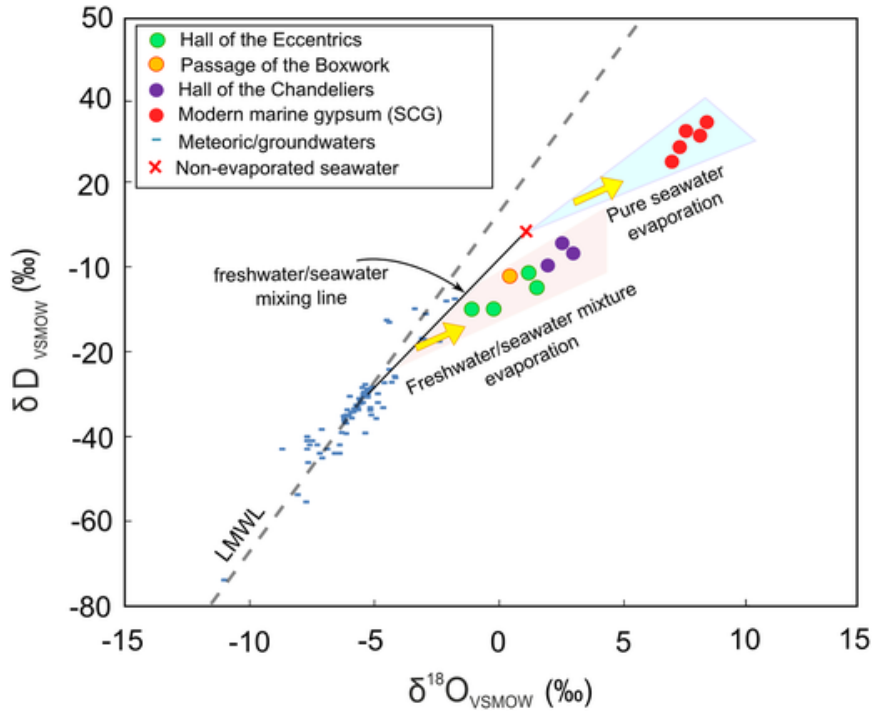

Fig. 5. Oxygen and hydrogen isotopes of speleothem-forming water in El Orón-Arco Cave obtained from gypsum hydration water after applying known isotope fractionation factors by Gázquez et al. (2017a) (see main text). Isotope composition of meteoric and groundwaters in SE Spain are given for comparison (Gázquez et al., 2017b), as well as the mother water from which marine gypsum formed in a nearby salt factory (Salina of Cabo de Gata, Almeria, SE Spain; Evans et al., 2015; Gázquez et al., 2017a). Analytical errors are smaller than the symbols.

\subsubsection{Strontium isotopes}

The ${ }^{87} \mathrm{Sr} /{ }^{86} \mathrm{Sr}$ of the analyzed gypsum speleothems is $0.70815 \pm 0.00005(n=3)$. The lowest value corresponds to the gypsum 'blisters' from the Hall of the Eccentrics (0.708095), while the highest ${ }^{87} \mathrm{Sr} /{ }^{86} \mathrm{Sr}$ value is found in the gypsum coatings from the Passage of the Debris (0.708188). The carbonate host-rock shows consistently lower ${ }^{87} \mathrm{Sr} /{ }^{86} \mathrm{Sr}$ values of $0.70779 \pm 0.00007(n=2)$. The ${ }^{87} \mathrm{Sr} /{ }^{86} \mathrm{Sr}$ of the water-soluble salt leaches from the host-rock display intermediate ${ }^{87} \mathrm{Sr} /{ }^{86} \mathrm{Sr}$ values between the gypsum speleothems and the host-rock of $0.70796 \pm 0.00004(n=2)$ (Fig. 6).

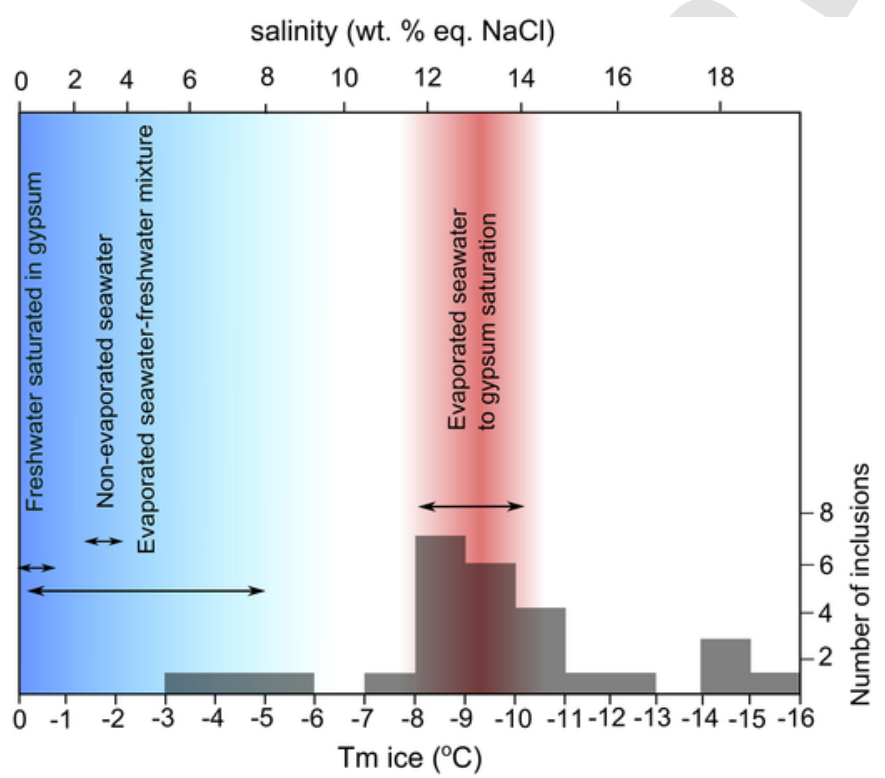

Fig. 6. Strontium isotope composition $\left({ }^{87} \mathrm{Sr} /{ }^{86} \mathrm{Sr}\right)$ of gypsum speleothems, carbonate host-rock and soluble salts leached from the host-rock in El Orón-Arco Cave. Analytical errors are smaller than the symbols.

\subsection{Fluid inclusions}

The ice melt temperatures $\left(\mathrm{T}_{\mathrm{m}}\right)$ of primary fluid inclusions in gypsum speleothems range from $-15.7^{\circ} \mathrm{C}$ to $-3.3^{\circ} \mathrm{C}(n=27)$, corresponding to salinities from 19.2 to $5.4 \mathrm{wt} \%$ eq. $\mathrm{NaCl}$. The gypsum 'chandeliers' (Fig. 3E) have the lowest $\mathrm{T}_{\mathrm{m}}\left(-10.7 \pm 2.5^{\circ} \mathrm{C} ; n=12\right)$ and therefore, the highest salinity of fluid inclusions $(14.2 \pm 2.5 \mathrm{wt} \%$ eq. $\mathrm{NaCl})$, while the gypsum spar on the tip of an aragonite stalactite (CT-23A1) from the Hall of the Eccentrics displays the highest $\mathrm{T}_{\mathrm{m}}\left(-5.5 \pm 1.9^{\circ} \mathrm{C}\right.$; $n=4)$ and lowest salinities $(8.2 \pm 2.5 \mathrm{wt} \%$ eq. $\mathrm{NaCl})$. Another gypsum spar (CT-21A; Fig. 3J) from the same chamber shows intermediate $\mathrm{T}_{\mathrm{m}}$ values $\left(-9.9 \pm 2.4^{\circ} \mathrm{C} ; n=11\right)$ and salinities $(13.7 \pm 2.4 \mathrm{wt} \%$ eq. $\mathrm{NaCl})$. Altogether, the mean $\mathrm{T}_{\mathrm{m}}$ is $-9.5 \pm 2.9^{\circ} \mathrm{C}$ and the salinity is $13.2 \pm 3.2 \mathrm{wt} \%$ eq. $\mathrm{NaCl}$, on average (Fig. 7 ).

\section{Discussion}

\subsection{Geomorphological and mineralogical evidence for sea salt weathering}

There is no physical evidence of either phreatic or vadose dissolution that would support conventional karstification mechanisms operating in the El Orón-Arco Cave today. As in many other 'flank margin coastal caves', El Orón-Arco Cave lacks both the typical morphologies related to water flow and indicators of subaqueous carbonate dissolution (e.g. scallops, smoothed surfaces or cupolas, etc.) (Mylroie and Mylroie, 2007). In contrast, the cavity displays clear evidence of recent mechanical weathering processes (Fig. 8). It should be noted that, while there is no evidence for conventional speleogenesis within El Orón-Arco Cave, it cannot be ruled out that the initial stages of the cave speleogenesis were controlled by phreatic or vadose dissolution processes. This may have led to the enlargement of the subterranean network before the stage of physical weathering. The signs of such hypothetical dissolution mechanisms might have been masked by the subsequent effects of subaerial sea salt weathering. In addition, the motion of faults system that runs parallel to the cliff of the Cabo Tiñoso may have played a main role in the initial stages of the cave formation by creating preferential groundwater pathways that favored the karstification of the carbonate host-rock.

The unsorted carbonate host-rock fragments ( $<1 \mathrm{~mm}$ to tens of centimeters) that rest against the walls of the 'Passage of the Debris' and in the entrance of the 'Passage of the Boxwork' provide strong evidence of a mechanical cave-forming mechanism that has operated in the cave at least in recent times (Fig. 2D). The cave walls and ceilings

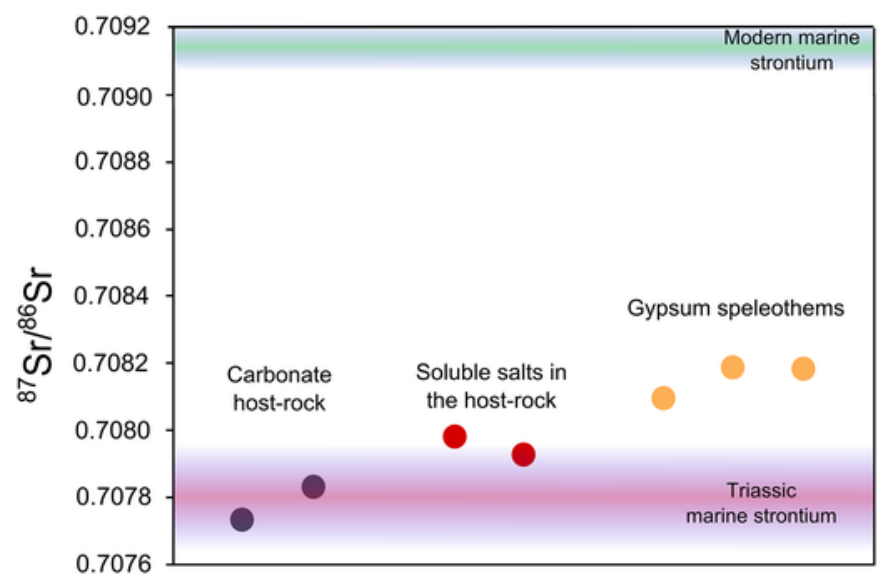

Fig. 7. Microthermometry of primary fluid inclusions in gypsum speleothems from El Orón-Arco Cave. Ice melt temperature $\left(\mathrm{T}_{\mathrm{m}}\right)$ of fluid inclusions were converted to salinity (wt\% eq. NaCl) using the equation of Bodnar (1993). 

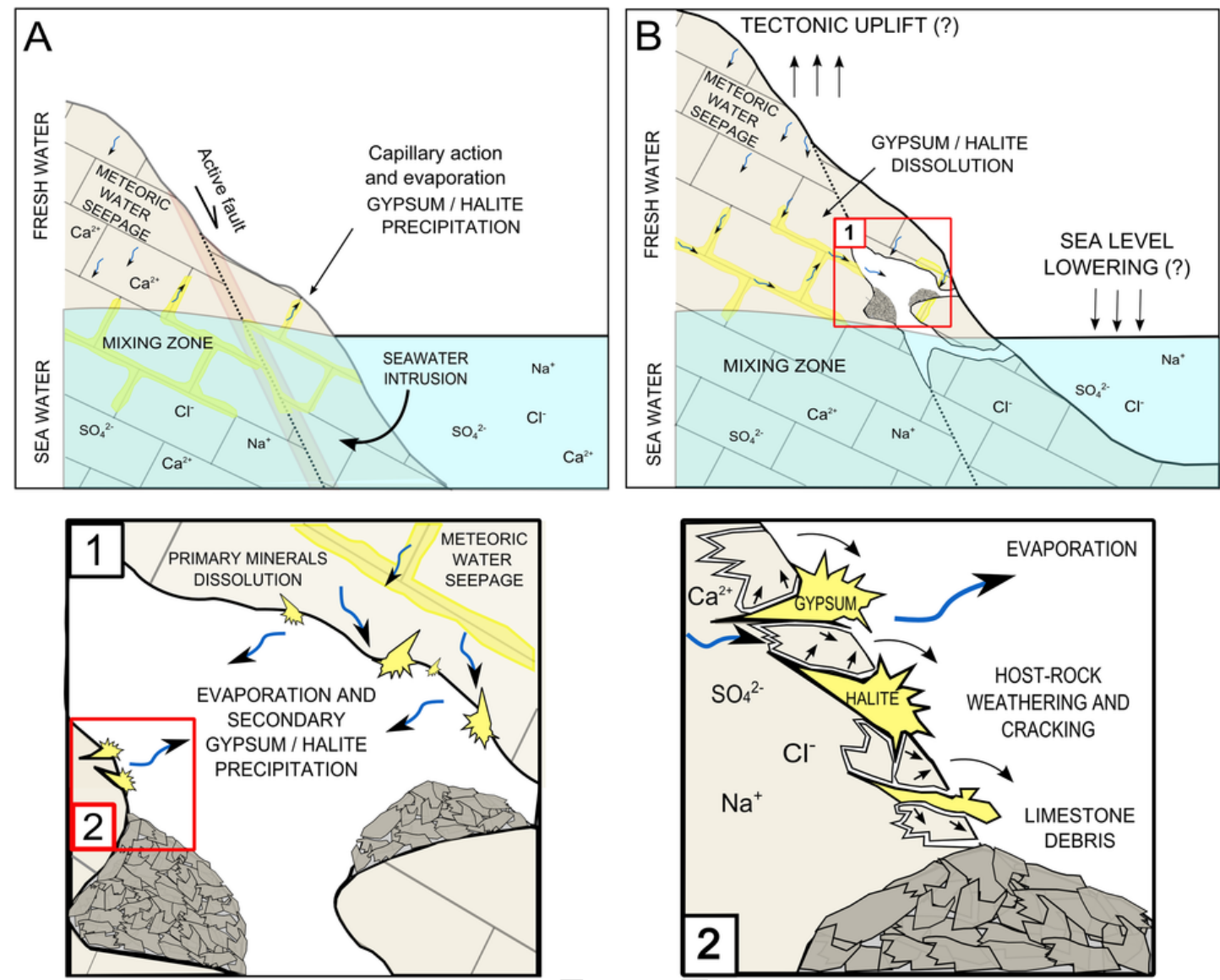

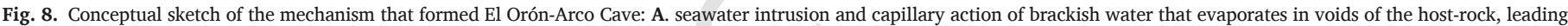

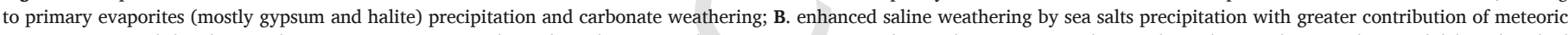

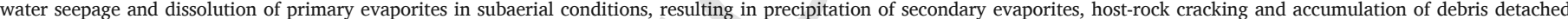

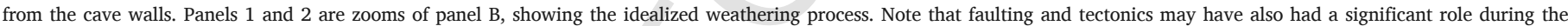
formation of the cave and meteoric water flow thought the carbonate host-rock, particularly during its initial genetic stages.

are made of easily detachable rock that crack and eventually fall naturally to the cave floor, accumulating as piles of unsorted rubble. This process is currently active and was observed during our visits to the cave. Indeed, the accumulation of rock debris in the smaller passages (e.g. the access to the Passage of the Boxwork) represents a serious challenge when accessing the cave, since these galleries are prone to obstruction and frequently need to be unblocked by speleologists.

Mineralogical analyses of cave wall materials reveal the presence of minerals typically derived from evaporated seawater, including halite, gypsum and occasionally calcite (Table 1 ). The cave host-rock is predominantly composed of greyish limestone and reddish dolostone, the latter containing small amounts of iron oxides. In the planes of the carbonate beds, whitish and yellowish saline concretions and efflorescences are observed projecting out into the cave (Figs. 2C and 3C). A mechanism is needed to explain the presence of evaporitic minerals within the host-hock material and the formation of weathered debris on the cave floor.

We suggest that capillary action and infiltration of seawater through the carbonate formation of Cabo Tiñoso followed by evaporation of the solution in the cave results in the crystallization of evaporites in planes and pores, leading to 'gypsum/halite wedging' of the host-rock (Fig. 8). In the cave environment, evaporation of infiltrated seawater is favored by the relatively high air temperature in the cave $\left(\sim 19^{\circ} \mathrm{C}\right.$ during our visit in January 2012) and likely low relative humidity. Although relative humidity has not been measured in the cave, the presence of halite strongly indicates relatively dry conditions be- cause halite dissolves if atmospheric relative humidity is above $\sim 73 \%$ (Wexler and Hasegawa, 1954; Oerter et al., 2018).

The crystallization pressure generated by the formation of salts in pore spaces (e.g. Goudie and Viles, 1997; Rodriguez-Navarro and Doehne, 1999) caused fracking and disaggregation of the original Triassic dolostones and limestones. Moreover, the motion of the faults in the Cabo Tiñoso formation and eustatic sea-level changes may have played a role in the ejection of the disaggregated materials (Fig. 8). During periods of relatively high sea-level, parts of the cave passage (today mostly between 0 and 50 ma.s.l.) were likely submerged in a brackish aquifer. In this scenario, calcium ions could be released to the solution from the limestones and dolostones and, in combination with the $\mathrm{SO}_{4}{ }^{2-}$ from seawater, result in the oversaturation of the solution for gypsum $\left(\mathrm{SI}_{\text {gyp }}>0\right)$ and subsequent mineral precipitation in cracks and pores of the carbonate host-rock (see Section 5.3) (Fig. 8A). During periods of relatively low sea-level, these primary evaporites would dissolve because of circulation of meteoric/brackish water mixture undersaturated in gypsum and halite (Fig. 8B). The solution enriched in dissolved salts could evaporate in the voids of the rock and the crystallization pressure generated by the secondary minerals would result in a significant sea salt weathering mechanism, as shown in Fig. 8.

The 'gypsum/halite wedging' process described above is a relatively uncommon mechanism in caves and has only been described in a few subterranean sites, including the Mammoth cave system in Kentucky, USA (White and White, 2003), the Friars Hole cave system in West Virginia, USA (Jameson, 1991), and some caves of the Nullarbor Plain, Australia (Lowry and Jennings, 1974). Also, it is well docu- 
mented that similar processes of capillary action of saline waters and crystallization of salts are responsible for the decay of building materials and limestone sculptures (e.g. Cardell et al., 2008; Gómez-Laserna et al., 2013; Gázquez et al., 2015b) and contribute to the formation of geomorphological features, such as honeycombs, alveoles and tafoni, especially in dry regions (Prebble, 1967; Beaumont, 1968; Bradley et al., 1978; Goudie and Day, 1980; Mustoe, 1982; Mottershead, 1989). We use stable isotopes to test the sea salt weathering hypothesis in Sections 5.2 and 5.3 .

\subsection{Identification of sulfate sources}

The $\delta^{18} \mathrm{O}_{\mathrm{SO} 4}$ and $\delta^{34} \mathrm{~S}$ of secondary gypsum deposits in El Orón-Arco Cave are generally lower than those expected for gypsum formed solely from modern seawater $\left(\delta^{18} \mathrm{O}_{\mathrm{SO} 4} \sim 9\right.$ and $\delta^{34} \mathrm{~S} \sim 21 \%$ ) (Fig. 4). The only samples that show seawater-like sulfate isotopic composition are the gypsum crusts on the dolomite boxwork formations found in the Passage of the Boxwork. In a $\delta^{18} \mathrm{O}_{\mathrm{SO}}{ }^{-} \delta^{34} \mathrm{~S}$ plot, the gypsum samples are positively correlated (slope of 1.3 ) and have $\delta^{18} \mathrm{O}_{\mathrm{SO} 4}$ and $\delta^{34} \mathrm{~S}$ down to $3 \%$ and $16.5 \%$, respectively.

During crystallization from the solution, gypsum precipitates with a negligible sulfur isotope fractionation (Raab and Spiro, 1991; Van Driessche et al., 2016), but as much as a $3 \%$ offset for oxygen isotopes, although the latter isotopic fractionation factor is poorly constrained (Van Driessche et al., 2016). If the sulfate that formed the gypsum was derived directly from seawater, the $\delta^{18} \mathrm{O}_{\mathrm{SO} 4}$ and $\delta^{34} \mathrm{~S}$ of the gypsum should reflect seawater values. Subsequent solution-reprecipitation of the gypsum in water with a similar $\delta^{18} \mathrm{O}_{\mathrm{SO} 4}$ and $\delta^{34} \mathrm{~S}$ should not alter the $\delta^{18} \mathrm{O}_{\mathrm{SO} 4}$ and $\delta^{34} \mathrm{~S}$ of the gypsum significantly (Evans et al., 2015). Our observations in El Orón-Arco Cave show that gypsum speleothems have significantly lower oxygen and sulfur isotope values than modern marine sulfate, so direct gypsum precipitation from seawater cannot completely explain our observations.

The lower $\delta^{18} \mathrm{O}_{\mathrm{SO} 4}$ and $\delta^{34} \mathrm{~S}$ may be derived from either (i) oxidation of isotopically ${ }^{34}$ S-depleted sulfur in sulfide minerals (e.g. pyrite) hosted in the carbonate bedrock (e.g. Audra et al., 2015) or (ii) the oxidation of aqueous sulfide previously reduced from marine sulfate by bacteria. Both sulfide minerals and aqueous sulfide take at least one of their oxygen atoms from water upon oxidation, producing sulfate that is more depleted in both the ${ }^{34} \mathrm{~S}$ and ${ }^{18} \mathrm{O}$ isotopes.

No sulfide mineralization has been identified in the cave or in our samples by mineralogical analyses. However, this region, including the nearby Sierras of Cartagena and Mazarrón $(\sim 20 \mathrm{~km}$ from El Orón-Arco Cave), hosts important $\mathrm{Zn}-\mathrm{Pb}-\mathrm{Cu}-\mathrm{Ag}$-Fe sulfide deposits that are related to volcanism and epigene hydrothermal activity (Esteban-Arispe et al., 2016). Most regional sulfide minerals have $\delta^{34} S$ values ranging from $+2 \%$ to $+15 \%$, and thus represent a potential source of ${ }^{34} \mathrm{~S}$-depleted sulfates to the cave system compared to marine sulfate (Table 1). We suggest that migration of fluids from depth through the faults system of Cabo Tiñoso can explain the $\delta^{18} \mathrm{O}_{\mathrm{SO} 4}$ and $\delta^{34} \mathrm{~S}$ values. This mechanism assumes oxidation of ${ }^{34} \mathrm{~S}$-depleted sulfide to sulfate occurred in deeper strata, followed by mobilization to the cave level and mixing with marine sulfate. Indeed, in other caves affected by 'gypsum wedging' (e.g. Mammoth cave system, Kentucky, US), the $\delta^{34} S$ values in gypsum $(-12 \%$ o to $+12 \%$ ) have been interpreted as being completely derived from oxidation of pyrite (Metzger et al., 2015). Thus, we suggest that, although oxidation of sulfide minerals is not the primary source of sulfate for gypsum precipitation in the El Orón-Arco Cave, mixing with marine sulfate can explain the observed $\delta^{34} \mathrm{~S}$ values. As for $\delta^{18} \mathrm{O}_{\mathrm{SO} 4}$, the relatively low $\delta^{18} \mathrm{O}_{\mathrm{SO} 4}$ observed in El Orón-Arco Cave can also be explained by oxidation of sulfide, which incorporates oxygen atoms from meteoric water that is typically depleted in the ${ }^{18} \mathrm{O}$ isotope (Van Stempvoort and Krouse, 1994; Onac et al., 2011).
Alternatively, mixing of aqueous sulfate derived from the oxidation of sulfide (previously reduced from seawater sulfate by bacteria) and marine sulfates may explain the relatively low $\delta^{34} \mathrm{~S}$ and $\delta^{18} \mathrm{O}_{\mathrm{SO} 4}$ in the gypsum speleothems in this cave. Microbial sulfate reduction produces ${ }^{34} \mathrm{~S}$-depleted sulfides, with maximum observed depletions of $-72 \%$ (Sim et al., 2011), whereas the oxidation of sulfide to elemental sulfur has a far lower sulfur isotope fractionation, producing enrichments in the ${ }^{34} \mathrm{~S}$ isotope on the order of $+8 \%$ (Zerkle et al., 2016). Complete oxidation of elemental sulfur to sulfate does not produce significant sulfur isotope fractionation (Zerkle et al., 2016 and references therein). Bacterial sulfur reduction and re-oxidation result in sulfates with low $\delta^{34} S$ and $\delta^{18} \mathrm{O}_{\mathrm{SO} 4}$ values. However, this mechanism requires anoxic conditions that may have never occurred in El Orón-Arco Cave, where the presence of organic matter is scarce, and oxygen concentration may have not been a limiting factor. In summary, the $\delta^{18} \mathrm{O}_{\mathrm{SO} 4}$ and $\delta^{34} \mathrm{~S}$ observed in El Orón-Arco Cave can be explained by mixing of seawater sulfate and isotopically lower sulfate derived from oxidation of sulfide minerals in depth and transported to the cave level though the faults system.

\subsection{Modes of gypsum/halite precipitation}

Gypsum precipitation has been identified as the cause of aqueous sulfate depletion in the fronts of marine water intrusions in coastal aquifers (Gomis-Yagües et al., 2000; Boluda-Botella et al., 2004). The meteoric-seawater mixture in the mixing zone of coastal aquifers is generally undersaturated in gypsum $\left(\mathrm{SI}_{\text {gyp }}<0\right)$. However, the intrusion front contains relatively high concentrations of dissolved ions (mostly $\mathrm{SO}_{4}{ }^{2-}, \mathrm{Cl}^{-}, \mathrm{Ca}^{2+}, \mathrm{Mg}^{2+}$ and $\mathrm{Na}^{+}$) that can interact with the carbonate bedrock. Magnesium and sodium can displace calcium in limestones and dolostones, resulting in an increase of calcium in the solution that, together with high sulfate concentrations in seawater, can lead to $\mathrm{SI}_{\text {gyp }}>0$ and gypsum precipitation (Gomis-Yagües et al., 2000; Boluda-Botella et al., 2004).

Strontium isotope ratios provide a tracer between marine-sourced fluids and other strontium-bearing fluids as each endmember is often characterized by different strontium concentrations and ${ }^{87} \mathrm{Sr} /{ }^{86} \mathrm{Sr}$. Because of the long residence time of strontium relative to the mixing time of the ocean, ${ }^{87} \mathrm{Sr} /{ }^{86} \mathrm{Sr}$ is homogeneous in the global ocean. Strontium in modern seawater has a radiogenic ${ }^{87} \mathrm{Sr} /{ }^{86} \mathrm{Sr}(0.70916)$ which differs significantly from other sources of strontium such as fluids produced from the weathering of silicate $(>0.720)$ and carbonate $(<0.708)$ lithologies (Elderfield, 1986). The host-rock of El Orón-Arco Cave shows relatively low ${ }^{87} \mathrm{Sr} /{ }^{86} \mathrm{Sr}$ values $(0.70779 \pm 0.00007)$, that are similar to those expected for Triassic marine carbonates (0.7078; McArthur et al., 2001). The ${ }^{87} \mathrm{Sr} /{ }^{86} \mathrm{Sr}$ of the gypsum speleothems is $0.70815 \pm 0.00005(n=3)$, thus displaying higher ${ }^{87} \mathrm{Sr} /{ }^{86} \mathrm{Sr}$ than those of the host-rock, but considerably lower ${ }^{87} \mathrm{Sr} /{ }^{86} \mathrm{Sr}$ than modern seawater. The soluble-salts leaches from the host-rock have intermediate ${ }^{87} \mathrm{Sr} /{ }^{86} \mathrm{Sr}$ between the Triassic carbonate and the speleothems (Fig. 6). This suggests that strontium in the speleothem-forming solution comes primarily from the Triassic carbonate $(\sim 75 \%)$ dissolution by brackish aquifer water before gypsum precipitation, rather than from modern marine strontium $(\sim 25 \%)$. This mechanism of host-rock dissolution was therefore also responsible for enhanced calcium concentration in the solution that lead to $\mathrm{SI}_{\mathrm{gyp}}>0$ and gypsum precipitation in cracks of the host-rock.

The gypsum precipitation process often requires evaporation of the fluid for the solution to reach $\mathrm{SI}_{\text {gyp }}>0$, as observed in other caves (Forti, 1996; Filippi et al., 2011; Gázquez et al., 2015c, 2017b). In such situations, $\delta^{18} \mathrm{O}$ and $\delta \mathrm{D}$ of the evaporated water normally produce a line in $\delta^{18} \mathrm{O}$ vs $\delta \mathrm{D}$ space with a slope $<8$. However, by adding calcium and sulfate to the solution, gypsum can precipitate directly from the solution with little evaporative enrichment. We test both hypotheses by 
studying the stable isotopes of GHW. Because the $\delta^{18} \mathrm{O}$ and $\delta \mathrm{D}$ is recorded by the structurally-bound hydration water of evaporative gypsum, evaporative processes (or lack therefor) can be constrained (Evans et al., 2015, 2018; Gázquez et al., 2017b, 2018).

The $\delta^{18} \mathrm{O}$ and $\delta \mathrm{D}$ values of the speleothem-forming solution in $\mathrm{El}$ Orón-Arco Cave do not fall in the field of non-evaporated seawater $\left(\delta^{18} \mathrm{O}\right.$ and $\delta \mathrm{D} \sim 0 \%$ ), nor do they indicate gypsum precipitation from evaporated seawater to the point of gypsum saturation (e.g. Evans et al., 2015; Gázquez et al., 2017a), which displays much greater $\delta^{18} \mathrm{O}$ and $\delta \mathrm{D}$ values than observed. Instead, the isotope values of the speleothem-forming water fall on an evaporation line that probably departed from an intermediate point between seawater values and the meteoric water seepage $\left(\delta^{18} \mathrm{O}\right.$ of $\sim-5 \%$ and $\delta \mathrm{D}$ of $\sim-40 \%$ in SE Iberian Peninsula; e.g. Gázquez et al., 2017b) (Fig. 5). This demonstrates that (1) the speleothem-forming solution was a mixture of fresh-meteoric water and seawater and (2) that this solution underwent significant evaporation in the cave before gypsum precipitation.

Surprisingly, the salinity of the speleothem-forming waters $(13.2 \pm 3.2 \mathrm{wt} \%$ eq. $\mathrm{NaCl})$ was considerably higher than expected for gypsum formed from an evaporated brackish solution (i.e. 4-8 wt\% eq. $\mathrm{NaCl}$; Attia et al., 1995; Natalicchio et al., 2014; Evans et al., 2015) and more similar to the salinity of fluid inclusions in purely evaporated seawater to gypsum saturation (i.e. $\sim 12-14 \mathrm{wt} \%$ eq. $\mathrm{NaCl}$ ). This apparent discrepancy between the results of stable isotopes in GHW and salinity of fluid inclusions can be explained by a mechanism involving (1) remobilization of halite/gypsum previously precipitated in cracks of the host-rock that is easily dissolved by water undersaturated in halite and gypsum (e.g. meteoric/seawater mixture); and (2) evaporation once the solution reaches the cave, resulting in precipitation of gypsum with relatively high salinity of fluid inclusions, but relatively low $\delta^{18} \mathrm{O}$ and $\delta \mathrm{D}$ values (Fig. 8). Alternatively, partial post-depositional isotopic exchange of GHW with an isotopically ${ }^{18} \mathrm{O}$-depleted source (i.e. meteoric waters) or gypsum reprecipitation, particularly in the case of microcrystalline gypsum speleothems (e.g. Fig. 3I), could be argued (Sofer, 1978; Pierre, 2018). However, this alteration may also derive secondary fluid inclusions with lower salinities, which have not been observed in the analyzed samples from El Orón-Arco Cave.

\section{Conclusions}

We demonstrate that the genesis of El Orón-Arco Cave was linked to the motion of faults that runs parallel to the cliff of the Cabo Tiñoso, and to salt weathering of the carbonate host-rock by infiltration and capillary action of seawater that subsequently evaporates within the cave, leading to precipitation of evaporite minerals (gypsum and halite) in pores and planes of the carbonate. The crystallization pressure of salts produces cracking of the host-rock at different scales. The detached rock fragments accumulate in piles that rest against the cave walls. The same process of seawater infiltration is responsible for the precipitation of gypsum and halite in speleothems of uncommon morphology, including gypsum chandeliers, halite soda-straws and gypsum blisters.

The source of sulfates for gypsum precipitation is predominantly marine, although the $\delta^{34} \mathrm{~S}$ and $\delta^{18} \mathrm{O}_{\mathrm{SO} 4}$ results are lower than those expected during the formation from modern seawater alone, suggesting a mixing of marine source fluids with an isotopically depleted sulfate source (i.e. oxidation of sulfide minerals). The isotopic composition of GHW and relatively high salinity of fluid inclusion in gypsum crystals can be explained by recycling of evaporites (gypsum and halite) from previous stages and gypsum reprecipitation in the form of speleothems. The salt-weathering mechanism proposed here for the formation of El Orón-Arco Cave is probably not an isolated case and may be responsible for the formation of other caves elsewhere, both in coastal environ- ments of dry regions and saline settings (e.g. caves associated to saline diapirs).

\section{Uncited reference}

Böttcher et al., 1998

\section{Acknowledgements}

The authors are grateful to all the speleologists that collaborated in the survey in El Orón-Arco Cave, and to Dr. Gilad Antler and Mr. James Rolfe for assistance with $\delta^{34} S$ and $\delta^{18} \mathrm{O}$ analyses in sulfates. This research was funded by the ERC WIHM Project (\#339694) to DAH, the Water Resources and Environmental Geology Research Group (University of Almería) and the Department of Physics of Condensed Matter at University of Valladolid (Spain). FG was financially supported by the "HIPATIA" research program of the University of Almería. Surveys and sampling in the cave were supported by the Federación de Espeleología de la Región de Murcia and RODCLE®.

\section{References}

Attia, O.E., Lowenstein, T.K., Wali, A.M.A., 1995. Middle Miocene gypsum, Gulf of Suez: marine or nonmarine?. J. Sediment. Res. 65A (4), 614-626.

Audra, Ph., Palmer, A., 2015. Research frontiers in speleogenesis. Dominant processes, hydrogeological conditions and resulting cave patterns. Acta Carsolog 44 (3), 315-348.

Audra, Ph., Gázquez, F., Rull, F., Bigot, J.Y., Camus, H., 2015. Hypogene sulfuric acid speleogenesis and rare sulfate minerals in Baume Galinière Cave (Alpes-de-Haute-Provence, France). Record of uplift, correlative cover retreat and valley dissection. Geomorphology 247, 25-34.

Beaumont, P., 1968. Salt weathering on the margin of the Great Kavir, Iran. Geol. Soc. Am. Bull. 79, 1683-1684.

Bodnar, R., 1993. Revised equation and table for determining the freezing point depression of $\mathrm{H}_{2} \mathrm{O}-\mathrm{NaCl}$ solutions. Geochim. Cosmochim. Acta 57 (3), 683-684.

Boluda-Botella, N., Gomis-Yagües, V., Ruiz-Beviá, F., Saquete-Ferrándiz, M.D., 2004. Gypsum precipitation/dissolution during seawater intrusion. In: 18th Salt Water Intrusion Meeting, (Cartagena (Spain)

Bradley, W.C., Hutton, J.T., Twidale, C.R., 1978. Role of salts in development of granitic tafoni, South Australia. J. Geol. 86, 647-654.

Cardell, C., Benavente, D., Rodriguez-Gordillo, J., 2008. Weathering of limestone building material by mixed sulfate solutions. Characterization of stone microstructure, reaction products and decay forms. Mate Charact 59, 1371-1385.

Chen, F., Turchyn, A.V., Kampman, N., Hodell, D., Gazquez, F., Maskell, A., Bickle, M.J., 2016. Isotopic analysis of sulfur cycling and gypsum vein formation in a natural $\mathrm{CO}_{2}$ reservoir. Chem. Geol. 436, 72-83.

Davis, D.G., 2000. Extraordinary features of Lechuguilla Cave, Guadalupe Mountains. J. Cave Karst Stud. 62, 147-157.

Elderfield, H., 1986. Strontium isotope stratigraphy. Palaeogeogr. Palaeoclimatol, Palaeoecolog. 57 (1), 71-90.

Esteban-Arispe, I., Velasco-Roldán, F., Boyce, A.J., Morales-Ruano, S., Yusta, I., Carrillo-Rosúa, J., 2016. Unconventional non-magmatic sulfur source for the Mazarrón $\mathrm{Zn}-\mathrm{Pb}-\mathrm{Cu}-\mathrm{Ag}$-Fe epithermal deposit (SE Spain). Ore Geol. Rev. 72, 1102-1115.

Evans, N.P., Turchyn, A.V., Gázquez, F., Bontognali, T.R.R., Chapman, H.J., Hodell, D.A., 2015. Coupled measurements of $\delta^{18} \mathrm{O}$ and $\delta \mathrm{D}$ of hydration water and salinity of fluid inclusions in gypsum from the Messinian Yesares Member, Sorbas Basin (SE Spain). Earth Planet. Sci. Lett. 430, 499-510.

Evans, N.P., Bauska, T.K., Gázquez, F., Brenner, M., Curtis, J.H., Hodell, D.A., 2018. Quantification of drought during the collapse of the classic Maya civilization. Science 361 (6401), 498-501.

Filippi, M., Bruthans, J., Palatinus, L., Zare, M., Asadi, N., 2011. Secondary halite deposits in the Iranian salt karst: general description and origin. Int. J. Speleol. 40 (2), 141-162.

Forti, P., 1996. Speleothems and cave minerals in gypsum caves. Int. J. Speleol. 25, 91-104.

García-Tortosa, F.J., López-Garrido, A., Sanz de Galdeano, C., 2000. Las unidades de Cabo Tiñoso y Peñas Blancas: Revisión y caracterización estratigráfica de las unidades alpujárrides del sector entre Mazarrón y Cartagena (Murcia, España). Estud. Geol.-Madrid 56, 31-40.

Gázquez, F., Mather, I., Rolfe, J., Evans, N.P., Herwartz, D., Staubwasser, M., Hodell, D.A., 2015. Simultaneous analysis of ${ }^{17} \mathrm{O} /{ }^{16} \mathrm{O},{ }^{18} \mathrm{O} /{ }^{16} \mathrm{O}$ and ${ }^{2} \mathrm{H} /{ }^{1} \mathrm{H}$ of gypsum hydration water by cavity ring-down laser spectroscopy. Rapid Commun. Mass Spectrom. 29, 1997-2006.

Gázquez, F., Calaforra, J.M., Forti, P., DeWaele, J., Sanna, L., 2015. The role of condensation in the evolution of dissolutional forms in gypsum caves: study case in the karst of Sorbas (SE Spain). Geomorphology 229, 100-111. 
Gázquez, F., Rull, F., Medina, J., Sanz-Arranz, A., Sanz, C., 2015. Linking groundwater pollution to the decay of 15th-century sculptures in Burgos Cathedral (northern Spain). Environ. Sci. Pollut. Res. 22, 15677-15689.

Gázquez, F., Evans, N.P., Hodell, D.A., 2017. Precise and accurate isotope fractionation factors $\left(\alpha^{17} \mathrm{O}, \alpha^{18} \mathrm{O}\right.$ and $\left.\alpha \mathrm{D}\right)$ for water and $\mathrm{CaSO}_{4} \cdot 2 \mathrm{H}_{2} \mathrm{O}$ (gypsum). Geochim. Cosmochim. Acta 198, 259-270.

Gázquez, F., Calaforra, J.M., Evans, N.P., Hodell, D.A., 2017. Using stable isotopes $\left(\delta^{17} \mathrm{O}\right.$, $\delta^{18} \mathrm{O}$ and $\delta \mathrm{D}$ ) of gypsum hydration water to ascertain the role of water condensation in the formation of subaerial gypsum speleothems. Chem. Geol. 452, 34-46.

Gázquez, F., Morellón, M., Bauska, T., Herwartz, D., Surma, J., Moreno, A., Staubwasser, M., Valero-Garcés, B., Delgado-Huertas, A., Hodell, D.A., 2018. Triple oxygen and hydrogen isotopes of gypsum hydration water for quantitative paleo-humidity reconstruction. Earth Planet. Sci. Lett. 481, 177-188.

Ginés, A., Ginés, J., 2007. Eogenetic karst, glacioeustatic cave pools and anchialine environments on Mallorca Island: a discussion of coastal speleogenesis. Int. J. Speleol. 36, $57-67$.

Gómez-Laserna, O., Olazabal, M.A., Morillas, H., Prieto-Taboada, N., Martinez-Arkarazo, I., Arana, G., Madariaga, J.M., 2013. In-situ spectroscopic assessment of the conservation state of building materials from a palace house affected by infiltration water. J. Raman Spectrosc. 44, 1277-1284.

Gomis-Yagües, V., Boluda-Botella, N., Ruiz-Bevia, F., 2000. Gypsum precipitation as an explanation for the decrease of sulfate concentration during seawater intrusion. J. Hydrol. 228, 48-55.

Gordillo, A., Espinosa, J., Martin, J.M., Pérez, A., 1972. Mapa Geológico Cartagena. 1:50.000. IGME

Goudie, A.S., Day, M.J., 1980. Disintegration of fan sediments in Death Valley, California, by salt weathering. Phys. Geogr. 1, 126-137.

Goudie, A.S., Viles, H.A., 1997. Salt Weathering. Wiley, Chichester, (241 pp).

Hodell, D.A., Turchyn, A.V., Wiseman, C.J., Escobar, J., Curtis, J.H., Brenner, M., Gilli, A., Mueller, A.D., Anselmetti, F., Ariztegui, D., Brown, E.T., 2012. Late glacial temperature and precipitation changes in the lowland Neotropics by tandem measurement of $\delta^{18} \mathrm{O}$ in biogenic carbonate and gypsum hydration water. Geochim. Cosmochim. Acta 77, 352-368.

Jameson, R.A., 1991. Concept and classification of cave breakdown: an analysis of patterns of collapse in Friars Hole Cave System, West Virginia. In: Kastning, E.H., Kastning, K.M. (Eds.), Appalachian Karst. National Speleological Society, Huntsville, AL, pp. 35-44.

Liu, T., Artacho, E., Gázquez, F., Walters, G., Hodell, D.A., 2018. Prediction of equilibrium isotopic fractionation of the gypsum/bassanite/water system using first-principles calculations. Geochim. Cosmochim. Acta 244, 1-11.

Llamusí, J.L., Ingles, S., Ros, A., Rodríguez, A., Pérez, C., 1990. Cavidades Submarinas del Cabo Tiñoso (Cartagena). Revista Caliza 1, 24

Lowry, D.C., Jennings, J.N., 1974. The Nullarbor Karst Australia: Zeitschrift für Geomorphologie. vol. 18, 35-81.

Maltsev, V.A., Self, C.A., 1992. Cupp-Coutunn cave system, Turkmenia, Central Asia. Proceedings of the University of Bristol speleological. Society 19, 117-149.

Martín, D., 2004. Programa para el análisis por difracción de rayos X. Método en Polvo (XPowder). Universidad de Granada.

McArthur, J., Howarth, R., Bailey, T., 2001. Strontium isotope stratigraphy: LOWESS version 3: best fit to the marine Sr-isotope curve for 0-509 Ma and accompanying look-up table for deriving numerical age. J. Geol. 109 (2), 155-170.

Metzger, J.G., David, A., Fike, D.A., Osburn, G.R., Guo, C.J., Aadison, A.N., 2015. The source of gypsum in Mammoth Cave, Kentucky. Geology 43, 187-190.
Moore, D.G., 1954. Origin and development of sea caves. Nat. Speleol. Soc. Bull. 16, 71-76.

Mottershead, D.N., 1989. Rates and patterns of bedrock denudation by coastal salt spray weathering: a seven-year record. Earth Surf. Process Landforms. 14, 383-398.

Mustoe, G.E., 1982. The origin of honeycomb weathering. Geol. Soc. Am. Bull. 93, 108-115.

Mylroie, J.E., Carew, J.L., 1990. The flank margin model for dissolution cave development in carbonate platforms. Earth Surf. Process. Land. 15, 413-424.

Mylroie, J.R., Mylroie, J.E., 2007. Development of the carbonate island karst model. J. Cave Karst Stud. 69 (1), 59-75.

Natalicchio, M., Dela Pierre, F., Lugli, S., Lowenstein, T.K., Feiner, S.J., Ferrando, S., Manzi, V., Roveri, M., Clari, P., 2014. Did Late Miocene (Messinian) gypsum precipitate from evaporated marine brines? Insights from the Piedmont Basin (Italy). Geology $42,179-182$.

Oerter, E., Singleton, M., Davisson, M., 2018. Hydrogen and oxygen stable isotope dynamics of hyper-saline and salt-saturated aqueous solutions. Geochim. Cosmochim. Acta 238, 316-328.

Onac, B.P., Wynn, J.G., Sumrall, J.B., 2011. Tracing the sources of cave sulfates: a unique case from Cerna Valley, Romania. Chem. Geol. 288, 105-114.

Pierre, C., 2018. The isotopic record of gypsum diagenesis in diluted solutions: observations in natural salinas and experiments. Chem. Geol. 493, 451-457.

Prebble, M.M., 1967. Cavernous weathering in the Taylor Dry Valley, Victoria Land, Antarctica. Nature 216, 1194-1195.

Puch, C., 1998. Grandes Cuevas Y Simas de España, Barcelona. 781-782

Raab, M., Spiro, B., 1991. Sulfur isotopic variations during seawater evaporation with frac tional crystallization. Chem. Geol. 86, 323-333.

Rodriguez-Navarro, C.E., Doehne, E., 1999. Salt weathering: influence of evaporation rate, supersaturation and crystallization pattern. Earth Surf. Process Landforms 24 191-209.

Sarrazin, P., Chipera, S., Bish, D., Blake, D., Vaniman, D., 2005. Vibrating sample holder for XRD analysis with minimal sample preparation. International Centre for Diffraction Data. Adv. X-ray Anal. 48, 156-164.

Sim, M.S., Bosak, T., Ono, S., 2011. Large sulfur isotope fractionation does not require disproportionation. Science 333, 74-77.

Sofer, A., 1978. Isotopic composition of hydration water of gypsum. Geochim. Cosmochim. Acta 42, 1141-1149.

Van Driessche, A.E.S., Canals, A., Ossorio, M., Reyes, R.C., García-Ruiz, J.M., 2016. Unraveling the sulfate sources of (giant) gypsum crystals using gypsum isotope fractionation factors. J. Geol. 124, 235-245.

Van Stempvoort, D.R., Krouse, H.R., 1994. Controls of sulfate $\delta^{18} \mathrm{O}$ : a general model and application to specific environments. In: Alpers, C., Blowes, D. (Eds.), Environmenta Geochemistry of Sulfide Oxidation. American Chemical Society Symposium Series vol. 550, pp. 446-480.

Wexler, A., Hasegawa, S., 1954. Relative humidity-temperature relationships of some saturated salt solutions in the temperature range $0{ }^{\circ} \mathrm{C}$ to $50^{\circ} \mathrm{C}$. J. Res. Natl. Bur. Stand. 53, 19, (RP 2512).

White, W.B., White, E.L., 2003. Gypsum wedging and cavern breakdown: studies in the mammoth cave system. Kentucky: Journal of Caves and Karst Studies 65, 43-52.

Zerkle, A.L., Jones, D.S., Farquhar, J., Macalady, J.L., 2016. Sulfur isotope values in the sulfidic Frasassi cave system, central Italy: a case study of a chemolithotrophic $S$ based ecosystem. Geochim. Cosmochim. Acta 173, 373-386. 